\title{
Consideraciones sobre la poética de Claudio Rodríguez
}

\section{Considerations on the Poetics of Claudio Rodríguez}

\author{
Miguel Ángel Muro \\ Universidad de La Rioja
}

\section{RESUMEN}

El propósito de este artículo es estudiar la poética de Claudio Rodríguez, deslindando sus componentes y tratando de clarificarlos y presentarlos en su conjunto. El autor dejó escritas algunas páginas sobre su concepción de la poesía que animan a la reflexión y, en algunos casos, a la interpretación. Así sucede con su concepción de la poesía como un don y una ebriedad, como alianza y condena o como celebración (que dan título a sus poemarios), o con nociones como las de «participación», «contemplación viva», «expresión viva» o «ritmo personal», que configuran su forma de entender el proceso poético.

Palabras Clave: Claudio Rodríguez, poética, don, ebriedad, alianza, condena, celebración, «participación», «contemplación viva», «expresión viva» y «ritmo personal».

\section{ABSTRACT}

The purpose of this paper is to study the poetics of Claudio Rodríguez, delimiting its components and trying to clarify them and to present them as a whole. The author left some pages written on his conception of poetry that encourage reflection and, in some cases, interpretation. So with his conception of poetry as a gift and inebriation, as an alliance and condemnation or celebration (giving title to his collections of poems), or with notions such as «participation», «living contemplation», «living expression» or «personal rhythm» that make up his way of understanding the poetic process.

Key words: Claudio Rodríguez, poetics, gift, inebriation, alliance, condemnation, celebration, «participation», «living contemplation», «living expression» and «personal rhythm».

La poesía de Claudio Rodríguez (Zamora, 1934-Madrid, 1999) no necesita, a estas alturas, ni presentación ni encomio. Su creación, singular, de voz propia, muy reconocible, cumple con el requisito que Rilke exigía para la buena obra de arte, al nacer de una vivencia honda y necesaria, y ejemplifica bien el alto cometido de indagación en la realidad que un compañero de promoción poética, José Ángel Valente, deparaba al verdadero poeta. Poetas relevantes de promociones posteriores han mostrado su aprecio y respeto por la 
poesía del autor zamorano, aun escribiendo desde posiciones poéticas poco cercanas: Guillermo Carnero, por ejemplo, salva a Claudio Rodríguez de «la tierra baldía» que era para los «novísimos» la literatura española del momento en que surgió su grupo (en Moral, 1980: 307); mientras que, por su parte, Luis García Montero señala a Claudio Rodríguez en El último tercio de siglo (1998: 664) como valiosa referencia para guiar el rumbo de su poesía. Los premios recibidos a lo largo de su vida ${ }^{1}$, la atención encomiástica de la crítica (Prieto de Paula, 1992) y, en fin, el aprecio de lectores de todo tipo ${ }^{2}$, dan buena cuenta de la valía de Claudio Rodríguez.

Recordado esto, las líneas que siguen se ocupan de la poética del autor, en un intento de conocer mejor sus componentes y acceder, con tal pertrecho, a una mejor comprensión (a una comprensión más rica) de sus poemas. El propio Claudio Rodríguez intentó definir su poética, si bien de forma algo elusiva y críptica, lo que anima a entablar un diálogo con sus escritos; diálogo en el que aportar una interpretación clarificadora o, sencillamente, prolongar la comunicación estética e intelectual con el autor y con su obra, en el convencimiento de que enriquecerá nuestro pensamiento estético.

\section{UNA CIERTA PREVENCIÓN DEL POETA ANTE LA CRÍTICA}

La labor y la responsabilidad del poeta se circunscriben a la creación. La reflexión sobre la poesía o sobre su propia poesía no le son exigibles. Hay poetas, como Gil de Biedma, que temen la acción negativa que esa reflexión puede tener sobre la creación, mientras que otros, como Benítez Reyes (1996), sospechan del creador que teoriza, por entender que hay un interés personal espurio en esa tarea. Claudio Rodríguez también manifiesta su prevención ante las poéticas que se instauran como preceptivas: «Un poeta — dice- no tiene una poética definida; siendo la poesía «un misterio y una aventura», una poética apriorística sólo puede llevar al fracaso del poema. (Rodríguez, 20041: 220). Esta prevención es llevada a un extremo negativo por el autor, contraponiendo la reflexión teórica a la belleza y la vivencia de la naturaleza (2004k: 196), en una toma de postura que recuerda a la de Dámaso Alonso al constatar los límites de la estilística como metodología de conocimiento de la obra de Garcilaso (1976: 104).

${ }^{1}$ Premio Adonais de Poesía (1953), por Don de la ebriedad, Premio de la Crítica (1965), por Alianza y Condena, Premio Nacional de Poesía (1983), por Desde mis poemas, Premio de las Letras de Castilla y León (1986), Premio Príncipe de Asturias de las Letras (1993), Premio Reina Sofía de Poesía Iberoamericana (1993) y Miembro de la RAE (1987).

${ }^{2}$ Valga el testimonio de Luis Mateo Díez en su discurso de ingreso en la R.A.E., donde reconocía su deuda lectora y creadora con el autor zamorano, cuyo sillón, vacante, venía a ocupar (Díez, 2011: 11-14). 
Desconfía Claudio Rodríguez, al respecto, de la capacidad de los críticos para establecer la poética de un autor, por entender que se hace sobre la obra terminada, sin atender al proceso creativo; proceso, a su entender, no sólo previo al poema, sino indesligable de este y de condición misteriosa. Entiende el poeta que tal estudio cae más cerca de la psicología que de la crítica literaria (Rodríguez, 2004h: 139 y 20041: 222-223), sin hacer alusión alguna a la crítica literaria psicológica que viene ocupándose de esos asuntos con aportaciones, cuando menos, sugestivas. El autor tampoco se ocupó de esta parcela de la estética.

No es singular, desde luego, ni privativa de Claudio Rodríguez esta postura del creador que considera misterioso e inefable el proceso poético y también el poema que resulta de él. Rilke, en la tercera de sus Cartas a un joven poeta, expresó con contundencia no sólo su desconfianza, sino su rechazo a la labor de la crítica literaria por considerarla incapaz de acceder a la ciudadela del misterio creador, a la que sólo se accedería mediante el amor. Valéry, por su parte, tenía claro que tampoco, y mucho menos, servía para explicar la creación artística nada que pudiera explicar la historia personal del autor, porque, en realidad, la generación de los poemas «sucede en lo íntimo del artista».

Sin embargo, Claudio Rodríguez no se encastilla en esta actitud respecto a la indagación poética, sino que acepta el reto (como viniendo a dar la razón a Baudelaire, en su apreciación de que un poeta lleva consigo a un crítico), y va cosechando o aceptando algunos planteamientos metodológicos que le parecen aceptables. Así, por ejemplo, hace suyo el racio-vitalista de Ortega (quien considera al artista el receptáculo de toda su condición humana y ésta del de toda la época en que vive), y reconoce el atractivo que tienen para él los escritos sobre la creación poética de poetas como Coleridge y Bécquer, no en cuanto a que hayan podido influir en su propia actividad poética, sino en cuanto a lo clarificador de sus hipótesis explicativas (Rodríguez, 20041: 224).

\section{Nociones QUE CONFORMAN LA POÉtiCA DE Claudio RodRÍGUEZ}

\subsection{Tensión entre objetividad y subjetividad}

En la base de la concepción poética de Claudio Rodríguez hay algunos presupuestos sustanciales de los que el poeta muestra clara conciencia y a los que aludió en sus escritos y lecturas de poemas. Uno de ellos es la tensión entre objetividad y subjetividad; principio tan sustancial en el vivir y el crear humanos, que Rodríguez tan sólo lo nombra, sin hacer mayor hincapié en él. Así, para tratar de explicar cómo se «encalma» el timbre de su poesía anterior en Alianza y condena, el poeta alude a la «tensión entre la objetividad y la subjetividad»y a los «niveles que ambos alcancen», como causa no sólo 
de las distintas modificaciones que puede tener el estilo, sino «hasta la vida misma» (1985: 20).

En realidad, como decía, se trata de una oposición básica en la epistemología general, cultural y literaria (Bobes, 1992), que se manifiesta sustancial en y desde el Romanticismo, debido al subrayado que esta forma de ver la vida y el arte hace de la subjetividad, entendiendo (en el caso de Fichte, sobre todo) que la conciencia es el fundamento de la experiencia y, por tanto, de su relación con lo que le es externo. Recuérdese cómo Hegel (1989: 748) funda en ella, entendida de forma dialéctica, la caracterización de los géneros, adjudicando a la lírica la condición de subjetiva; a la épica, la de objetiva; y al drama, la de síntesis superadora de ambas. Para el filósofo alemán, ya en la lírica se produce una importante relación entre la interioridad del poeta y el mundo exterior, ya que éste es atraído hacia aquella y convertido en algo interior (1989: 814 y 776, 779 y 800). En esta línea, García Berrio retrotrae esta dialéctica a los orígenes de la poesía, entendiendo que frente a la alienidad del canto de la heroicidad homérica, el poeta lírico se fijó como cometido «explorar y cotejar la realidad íntima con la exterior, a la medida de las necesidades míticas y sentimentales del autor del canto». (1998: 62).

Pero, volviendo a la poesía de Claudio Rodríguez, se han de constatar varios puntos a este respecto. No se trata sólo de comprobar la oposición entre los términos, sino de hacer hincapié en la tensión que hay entre ambos, que el poeta siente de forma acusada y que dota a su percepción de un gran dinamismo y movilidad entre un ámbito y el otro, lejos de cualquier estatismo y permanencia en los objetos poéticos o de la adopción de un lugar fijo en la observación poética (Prieto de Paula, 2011: 53) ${ }^{3}$. Es sobre esta dialéctica, por ejemplo, sobre la que se desarrolla el eje vertical de relación entre el poeta y lo otro, tan representativo de su poética y medular en ella (Prieto de Paula, 1989: 126; García Berrio, 1998: 72). En el desarrollo de esta dialéctica es también donde se produce el cotejo de la conciencia poética con las cosas y el resultado de la metamorfosis de ambas (García Berrio, 1998: 449), singularmente en Conjuros (García Berrio, 1998: 483). Asimismo, esa relación subjetivo-objetiva se sustancia en Claudio Rodríguez en un lugar o espacio que el poeta denominará como «sutura», espacio capital en su experiencia vital (de separación y desgarro familiar y social) y poética, encaminada de forma dramática y vehemente a encontrar ese contacto religador «entre el hombre y lo esencial del mundo». (Cañas, 1988: 26 y 85) o, en la formulación sartreana, la «synthese de l'existence et de l'être», objetivo de la actividad esencial del poeta, que denominará «contemplación viva» y que veremos más adelante.

\footnotetext{
${ }^{3}$ Condición dinámica que se hermana con la índole andariega de su creación poética y con la fugacidad de la permanencia del poeta entre las cosas, como percibe con sagacidad Tomás Sánchez Santiago (2011:39).
} 


\subsection{La poesía como un don y un fervor; «ebriedad de la existencia» y «cla- ridad»}

Más evidente que esta tensión entre lo subjetivo y lo objetivo, es en Claudio Rodríguez la forma de concebir la poesía como un don y como una ebriedad, que se manifiesta con pujanza y acierto en su primer libro, cuyo título, Don de la ebriedad, reúne las dos nociones y las manifiesta. La poesía concebida como algo que se recibe, un regalo (condición que no comenta Claudio Rodríguez), y una ebriedad, que el poeta entiende y explica como «un entusiasmo, en el sentido platónico de inspiración, de rapto, de éxtasis; lo que para el cristiano sería fervor». (Rodríguez, 1985: 12). Tal concepción poética no tiene origen racional sino sensitivo, y se produce o brota «del contacto directo» del alma del poeta con la realidad de su tierra zamorana y con el «pulso» de sus gentes, sensaciones percibidas a los diecisiete años que se irán debilitando con el paso del tiempo. Pero cuando esta conmoción se produce y da lugar a sus primeros libros, se manifiesta en una respuesta exaltada ante el hecho de vivir, de estar vivo; respuesta inmediata, sin matizaciones, sin presupuestos. Es la respuesta ante «el mero hecho de estar vivo». No está sosteniendo el poeta que esa sensación sea debida a merced alguna de un dios: utiliza la filosofía platónica para ser entendido, lo mismo que habla de «fervor» en el sentido cristiano, sin apuntar a causa alguna en esa dirección religiosa (Prieto de Paula, 1989: 107). El don, el regalo que supone la poesía no tiene un origen explícito: no hay un dios, como en el Ion, cuya mano toque al poeta dejándolo «poseído», imantado de una gracia particular que le permite poetizar y atraer a sí a quienes lo escuchan y contagiarlos de fervor. Si hay una causa original, eficiente, el poeta no la nombra: es una sensación y nace, como respuesta ante la maravilla de la constatación de la realidad y la vida, de la relación entre el alma del poeta y la realidad. Quizá ni siquiera sea lo adecuado preguntarse por el dador, por el origen del don. Quizá la palabra adecuada - contra el propio poeta- no sea «don», que necesita dos términos: el dador y el receptor, unidos con algo que se regala. En Claudio Rodríguez, de haber un dador, éste sería la propia vida, que toma conciencia de sí misma y se maravilla por su existencia y la de los demás seres, animados e inanimados, humanos y no humanos. Lord Byron subrayaba la importancia de la «sensación», como «el gran objeto de la vida», el mero y capital hecho de «sentir que existimos», y por ahí va, creo, la actitud de Claudio Rodríguez. Byron, romántico, precisaba que no importaba si esa sensación procedía del dolor (algo que no se considera por parte de Claudio Rodríguez, aunque también sea un componente sustancial en su poesía), y hacía un todo solidario con la búsqueda a la que empuja la existencia y la adquisición de lo encontrado.

De todos modos, a pesar de la importancia de «don»y de «ebriedad», para esta poética, hay que notar que ambas son nociones dependientes de otra prin- 
cipal. En su primer poema la palabra clave es «claridad» ${ }^{4}$, y en ella se produce una interesante e importante traslación de significado hacia la poesía y hacia el efecto poético: es la poesía la que produce esa claridad cognoscitiva de revelación del ser en su unidad a través de sus manifestaciones; y viceversa: la claridad sería el correlato de la poesía y de sus efectos. En el interior del poema es de la «claridad» de la que se dice que es un «don», no de la ebriedad, que también se nombra, pero como adjetivo de «persecución», de la persecución de la claridad. Esta «claridad» «viene del cielo»: es la única mención de procedencia del don, quedando «cielo» abierto a la ambigüedad de ser entendido en su sentido físico o metafóricamente, en sentido religioso o platónico. De la actividad y el efecto de esa claridad se predica poéticamente, en un vago neoplatonismo (que se manifiesta también en otros pasajes), que «ocupa» las cosas, «sedienta de una forma, / de una materia para deslumbrarla / quemándose a sí misma al cumplir su obra». Esta claridad está ya entrañada en las cosas, trascendiéndolas (Asís, 1977, Bradford, 1979), cuando conmociona al poeta: la revelación que proporciona es el asombro de la existencia; una revelación que se muestra también en su faceta aniquiladora («claridad sola / mortal como el abrazo de las hoces»), como en el clímax sexual o en la experiencia unitiva de los místicos. Fuera del poemario y de la reflexión, en el terreno de la anécdota reveladora, Claudio Rodríguez refería cómo, en el campo abierto, sentía miedo junto al asombro y al placer: «miedo a las cosas desconocidas», «miedo frente a las cosas». Y junto a este sentimiento, la pérdida de la sensación de tiempo o, mejor, el sentimiento del tiempo «como algo estático» (en Cañas, 1988: 23).

En el segundo poema de Don de la ebriedad, la voz poética confiesa una duda que apunta en la dirección de esa causa primera del don y de la ebriedad, y más en particular, a su ausencia: «Yo me pregunto a veces si la noche / se cierra al mundo para abrirse o si algo / la abre tan de repente que nosotros / no llegamos a su alba, al alba al raso / que no desaparece porque nadie / la crea: ni la luna, ni el sol claro». La conclusión (tras afirmar que nuestros sentidos gravitan hacia lo alto y no reparan en lo que ocurre a ras de tierra), es que «la mañana surge sin principio / ni fin, eterna ya desde el ocaso», aunque se pueda adjudicar al pensamiento: «Como avena / que se siembra a voleo y que no importa / que caiga aquí o allí si cae en tierra, / va el contenido ardor del pensamiento / filtrándose en las cosas, entreabriéndolas, / para dejar su resplandor y luego / darle una nueva claridad en ellas».

En el cuarto poema, sin embargo, la palabra clave es «deseo». Parece tratarse de un sentimiento pujante, de una fuerza que comparten el yo poético y la naturaleza, que el poeta se apropia. Ese deseo — se dice- «está en el mundo», «necesita vivir entre las cosas». Vuelve a haber un cierto aliento

\footnotetext{
${ }^{4}$ Como bien dice Prieto de Paula (1993: 101): «La claridad es el centro al que se vuelve en repetidas ocasiones a lo largo de todo el libro».
} 
mitológico en la presencia de este sentimiento que, en su condición de primordialidad o esencialidad, parece estar remitiendo al Eros de la mitología griega, pero no como el dios del amor o del deseo amoroso, sino como fuerza, impulso creativo, surgido tras el Caos primigenio, tal como lo expone Hesíodo en su Teogonía.

«Don» vuelve a aparecer en el séptimo poema, en este caso como fruto de la tierra, pero tampoco aquí se especifica ni sustancia el principio o la fuerza que remueve las tierras; cuando «don» se nombre en VII, será como lo dado por una cosecha trascendente.

En el libro segundo, el «Canto del caminar» tiene una estructura pragmática en la que el yo poético se dirige, primero, a algo o a alguien, sin precisar y, más adelante, se alude a un principio creador, innominado. La vida podría ser ese principio, como se nombra en el primer poema del Libro tercero: «Si la vida / me convocase en medio de mi cuerpo / como el claro entre pinos a la fría / respiración de luna»; pero en «A las estrellas», la pregunta por ese principio vital, germinador, es ya directa y acuciante, y no tiene respuesta, porque el poeta pasa, sin transición, a constatar la situación en que queda el corazón del hombre.

Descartó el propio poeta la adscripción de estos orígenes poéticos a la poesía de la naturaleza de los tratadistas del siglo XVIII, lo mismo que a la de los regeneracionistas y escritores como Unamuno y Machado, porque los separa de ellos en este poemario la irreflexividad, la inconsciencia del canto y su inmediatez. Condiciones éstas que explican «el tono irracional» de los poemas y que hacen que el poeta —al reflexionar sobre ello- caiga en la cuenta de la importancia preponderante del estado de ánimo, exaltado, por encima de los objetos que pudieran causar esa exaltación. Así, Claudio Rodríguez plantea lo que considera «un grave problema poético»: elucidar si «la experiencia es concreta» o no lo es. Lo que sí percibe es que esta exaltación de la que habla «carece de tema concreto», lo que hace - entre otras cosasque los poemas (salvo dos) de Don de la ebriedad no tengan título» (Rodríguez, 1985: 12).

Evidente y consecuentemente, esta exaltación inmediata de la vida se manifiesta en una forma poética que es pura exclamación irracional y simbólica. Como bien han analizado varios comentaristas de su obra (Bousoño, 1971, 1985; Prieto de Paula, 1993; García Jambrina, 1998), el poeta recurre a símbolos, imágenes y metáforas que, además, se vinculan entre sí de forma alógica, irracional y que producen en el lector un desbordamiento de su capacidad racional de comprensión. Por ello, el lector es convocado — piensa Jambrina- a una participación emotiva de la realidad esencial que el poeta ha contemplado y comunica. Pero no creo que se trate sólo de una participación emotiva, sino de que, en lo cognoscitivo, el lector debe recurrir a una descodificación propia de la conciencia mítica, efectuada mediante símbolos, cargados de significados no lógicos, tan sugerentes y multisignificativos cuanto imprecisos. 
Esta actitud vital y poética es, por tanto, básica, original y decisiva en el quehacer creativo de Claudio Rodríguez y, como manifiesta el poeta, no llega a perderse nunca en su poesía. Sucede, no obstante, que en su andadura poética, esa exaltación va siendo moderada o va siendo acompañada por la meditación $\mathrm{y}$, como nota bien el poeta, «en cuanto uno medita, deja de sentir esa ebriedad». De este modo, una segunda dialéctica (la que se da entre la exaltación de la vida y la meditación sobre ella), vendría a instalarse en la base de la poesía de Claudio Rodríguez y a explicarla, a dar razón de su ser: «Este — dice el poeta- podría ser un acercamiento hacia el proceso de mi poesía, que cada vez se va haciendo más reflexiva, pero sin perder el aspecto exaltador de la vida». (Rodríguez, 20041: 218-219). Así, Don de la ebriedad termina con la expresión de una duda sobre la duración de ese entusiasmo y su agotamiento ( ¿ Es que voy a vivir? ¿Tan pronto acaba la ebriedad?»), acabamiento que no se sustancia de forma abrupta en Conjuros, su segundo poemario, que viene a ser una continuación de Don de la ebriedad, al punto de que Claudio Rodríguez no los separaba cuando leía y comentaba poemas siguiendo el hilo de su itinerario poético. El comienzo de Conjuros retoma la sustancia íntima del poemario anterior, con sus componentes sustanciales, al hilo o ante la consideración o la contemplación o la participación de «la respiración de la llanura», a la que dedica el poema: «No sé cómo he vivido / hasta ahora ni en qué cuerpo he sentido / pero algo me levanta al día puro, / me comunica un corazón inmenso, / como el de la meseta, y mi conjuro / es el del aire, tenso / por la respiración del campo henchida / muy cerca de mi alma en el momento / en que pongo la vida / al voraz paso de cualquier aliento».

Y de nuevo, como en Don de la ebriedad, en este poemario, la procedencia de ese don que es la poesía permanecerá imprecisa. Pero es que, además, la «claridad» ya no es algo que se reciba sin esfuerzo; ahora será la condición de una cosecha, de un jornal, de algo que se logra tras la siembra o el trabajo, no algo que viene dado sin participación ni consciencia. En «A las puertas de la ciudad», el gran principio vital será el cielo, visto con la metáfora activa del arado, que se amasa con la metáfora también repetida del poeta como un surco arado. Y sin embargo, otra vez, más adelante, en «El canto de Linos (Salida a la labranza)», volverá la fuerza vital innominada, la que da razón de ser a toda cosa, que alienta en ellas, que guía la mano y la labor, la vida del hombre. Volverá a sustanciarse ese principio creador en «Cosecha eterna», con una precisión personificadora que no había en otros textos: «¿Quién con su mano eterna / nos siembra claro y nos recoge espeso?» Pero, otra vez más, se diluirá la posible referencia a una divinidad, para fundirse y diluirse en lo humano ( ${ }_{i} \mathrm{~A}$ ese, / parad a ese, a mí, paremos todos: / nuestra semilla al viento!» En el segundo libro de Conjuros, en el poema «A mi ropa tendida (el alma)», también la voz poética (se) preguntará por el agente que ha obrado la maravilla de restituirle la blancura, la pureza de la infancia, sin dar respuesta. La única concreción que hace el poeta se da en el «El ruido 
del Duero», haciendo al río, a su música la causa de la conmoción interior del yo poético.

La condición enfática, fervorosa, se mantiene, pues, en parte de Conjuros, pero en este poemario se invierte el signo del mito inicial del poeta, de búsqueda y huida, para convertirse en un regreso. Desde su título, vendría a apuntar hacia la palabra en su valor mágico, capaz de «conjurar» las amenazas y los peligros o, en sentido positivo, capaz de solicitar la ejecución de una acción determinada. Con los conjuros de sus poemas, Claudio Rodríguez estaría tratando de transfigurar la realidad en sus aspectos más habituales (García Berrio, 1998: 480) o de convocar a los otros hombres a compartir la verdad que le ha sido revelada en el momento de la ebriedad. La relación de la conciencia y las cosas a la que aludíamos más arriba se efectúa desde el afecto arrebatado y fervoroso (Cano, 1974: 156).

En los poemarios posteriores esta concepción de la vida y de la poesía casi desaparece por completo. En Alianza y condena sólo habrá una referencia sustancial, en la que el «don» será una limosna (¿o un don, en el sentido más estricto: un regalo inmotivado y generoso?); y ese cielo, de donde venía la claridad gozosa de Don de la ebriedad, ahora es solicitado para que acompañe, como por caridad.

Esta concepción poética está recorrida de punta a cabo en los primeros poemarios por un impulso ascensional, vigoroso e irreprimible, que ya notó y señaló Vicente Aleixandre al comentar el paso de Don de la ebriedad a Conjuros, matizando, además, con acierto cómo Claudio Rodríguez entendía y sentía el mundo «en trance de crecimiento».

Pero no se trata sólo del impulso ascensional de la naturaleza por crecer y hacerlo hacia lo alto. Este impulso comprende también (y quizá antes) la fuerza hacia la luz, la claridad y el cielo, que impregna toda su poesía y que traza en ella un eje vertical. Es algo que se expresa muy bien en el «Fragmento VII» de Don de la ebriedad, donde se habla del sol y del viento «que alza la vida»; o, mejor, en el «Canto del despertar» del «Libro segundo»: «El primer surco de hoy será mi cuerpo. / Cuando la luz impulsa desde arriba / despierta los oráculos del sueño / y me camina, y antes que al paisaje / va dándome figura», donde se ponen de manifiesto el poder de la luz y su actividad conformadora en las cosas y en el yo poéticos. Esta condición y esta actividad se sustancian más que en ningún otro poema en «El cerro de Montamarta dice», donde el cerro manifiesta su ansia ascensional y la tensión en la espera de los agentes (la luz, las mañanas, las puestas de sol, las noches) que vendrán a continuar y acabar una elevación que se siente incompleta y que ha servido al deseo de altura de los hombres. No es éste, sin embargo, un rasgo que se circunscriba a los primeros poemarios, aunque sea en ellos donde es más acusado; todavía en El vuelo de la celebración «el baile eterno de Águedas» baja de lo alto al corazón de los que danzan o se exhorta «Hacia la luz». 
Entendida y sentida la poesía como don, como ebriedad, como claridad, como impulso arrebatado hacia lo alto, la voz poética se manifiesta constituida, llevada y desbordada por una fuerza poderosa y desconocida, sobre la que el poeta confiesa repetidas veces una ignorancia activa y ansiosa. El mundo, sus seres y la vida que los recorre y alza, son símbolos que necesitan una interpretación que se revela dificultosa («Mi boca sólo llega al signo, / sólo interpreta muy confusamente»). Y es que el poeta afronta el misterio, constata o se le revela que «hay demasiadas cosas infinitas». Por eso, junto a las afirmaciones del desconocimiento, abundan las interrogaciones en todo el primer poemario, hasta en sus últimos versos: «¿Es que voy a morir? [..] / ¿Es que voy a vivir? ¿Tan pronto acaba / la ebriedad?». Esta ignorancia y esta expectación anhelante frente a un mundo asombroso y hermético se mantienen en Conjuros; pero en este poemario, la aparición de la actividad reflexiva va a dar lugar a que se explicite la dificultad de lo que ha de ser entendido y se deplore la pérdida de la inocencia cognoscitiva anterior.

\subsection{La poesía como alianza y condena}

De nuevo, —al decir del propio poeta-, el título de otro de sus libros recoge una concepción básica de la vida y de la poesía: «Alianza y condena» son dos actitudes básicas del ser humano: «lo que el hombre acepta y lo que condena» (Rodríguez, 1985: 19). Claudio Rodríguez manifiesta que para él no son «dos realidades distintas», sino que la vida «consiste en esas dos aceptaciones». La figura y el magisterio de Baudelaire asoman en una cita no literal: «Quiero cantar desde la propia carroña». Pero Claudio Rodríguez no sigue, no desenvuelve, todavía aquí, esta aceptación de la parte más desagradable de la vida en tensión con el ideal y su conversión en materia poética que iniciara en la modernidad el maestro francés ${ }^{5}$.

En este tercer poemario de su andadura poética, ya ha terminado el canto entusiasmado, y la palabra poética se aplica a la manifestación de la realidad, de la «verdad», en lo que tiene de aceptable y de condenable, llevando esa dialéctica hasta la composición de muchos de los poemas. El poeta ya no sólo ha perdido la exaltación ebria por la manifestación maravillosa de los seres, sino que también ha abandonado (o ha sido abandonado por) la nostalgia de aquel tiempo inaugural, que todavía podía verse en Conjuros. Ahora, hay una mirada distinta, hija de un desconcierto por esta pérdida, que constata los dos aspectos de la vida y se plasma en poemas como «Porque no poseemos», donde, tras expresar la ignorancia tras la pérdida de la sencillez, se afirma la

\footnotetext{
${ }^{5}$ Será en su último poemario, Casi una leyenda, donde se produzca una aceptación serena de la muerte y de su ámbito, con imágenes carnavalescas de una aceptación del final y su parafernalia, fiada en la regeneración.
} 
voluntad de detener una realidad fugitiva («acuñar las cosas, / detener su hosca prisa / de adiós, vestir, cubrir / su feroz desnudez de despedida») ${ }^{6}$.

Don de la ebriedad y Conjuros completaban el doble trayecto de la aventura poética del deseo, plasmada en la salida-huida como búsqueda, y la vuelta-regreso, minada de dificultades y adversidad, en lucha con una voluntad optimista de conciliación que no cede, pero que debe admitir la diversidad irreductible de los seres frente al ideal metafísico unitario y al bucolismo idílico en el que los contrarios se armonizaban en la naturaleza (García Berrio, 1998:749-763).

En este poemario de madurez, la desilusión y el desengaño producen un sentimiento de dolor algo resignado que mira con melancolía una posibilidad de armonía y felicidad que pudo darse y que, incluso, por breve tiempo, se dio. Y es que incluso el término «alianza» tiene en este poemario una resonancia negativa y pesimista (es una «aceptación»), si bien acoge el dinamismo positivo vital y poético del que nunca abdicó Claudio Rodríguez. Se trata, más bien, de un pacto, entendido como necesario para hacer menos dura la vida (Cañas, 1988: 58), pero no cabe duda de que ese pacto supone el reconocimiento del fracaso del ideal solidario fraternal; como apunta Prieto de Paula, para el poeta «alianza es lo contrario del amor, en cuanto que la relación humana surge de la necesidad de aliarse contra el miedo». (Prieto de Paula, 1993: 47).

\subsection{La poesía como celebración}

Una vez más, como en poemarios anteriores, El vuelo de la celebración apunta desde el título a otra actitud vital que se transmite o plasma en los poemas. Claudio Rodríguez alude en varias ocasiones a la vinculación entre poesía y fiesta. Ahora ya no se trata de la relación entre el hombre y la maravilla de lo que se le revela, sino de la convivencia, de la vinculación del hombre con los otros; se trata «del hombre integrado, o entregado en sus tareas colectivas, comunales. Sobre todo en la 'fiesta'. [...] El origen de la poesía consiste en la fiesta, en el festejo, en el festejar». (Rodríguez, 1985: 18). Pero Claudio Rodríguez no vincula la celebración sólo con la colectividad ni tampoco, desde luego, con la perfección del mundo; en realidad, el poeta celebra y canta («miserable el momento si no es canto»), desde la vida, en su variedad y complejidad ( $\ll$ Se celebra, se festeja desde cualquier circunstancia humana, desde el dolor, la angustia, la muerte, la alegría, los sueños...»), en una

${ }^{6}$ Habla Claudio Rodríguez de una modificación del «tono» para explicar este nuevo poemario, aunque no da una definición de esta noción, que queda, por tanto, imprecisa, abierta a una presumible comprensión por parte del receptor, como una más de esas nociones de las que tenemos un sentido aproximado. «Tono» (o «timbre», que usa como sinónimo) parece querer significar 'actitud desde la que se escribe', cuando dice que «No se modifica el timbre de mi poesía anterior, sino que se encalma. La forma (el poema) se acompasa con un tono más meditativo». (Rodríguez, 1985: 20). 
demostración continuada a través de todos sus poemarios de voluntad indomeñable de seguir adelante a pesar de todos los pesares.

Al hilo de esta constatación, se abre Claudio Rodríguez a un asunto capital que sólo anota, sin ulterior reflexión y con cierta confusión: el hecho de que una realidad desagradable pueda ser causa de placer cuando es trascendida por la estética ${ }^{7}$; pero, como ya notó Aristóteles en su Poética (1994:24) (y con el ejemplo del cadáver también, por cierto), esto es, antes que nada, condición y cualidad de la mímesis, no del canto que festeja o que lamenta.

El objeto de la celebración, por tanto, es la vida en su totalidad sin sesgo a favor de unas facetas de la realidad, las positivas, en detrimento de otras, las negativas. Bien al contrario, el poeta afirma celebrar «lo que se abre o lo que se cierra desde todas las posibilidades vitales», y matiza: «la figura de las cosas, el poderío de las sensaciones que pueden desembocar en feracidad y en sequía». Si parecía que bastaba al poeta el sentido habitual de «celebración», estas precisiones sobre el objeto celebrado lo problematizan, lo hacen complejo y personal. Sin que quede claro que se refiere a la actividad de celebrar, dice Claudio Rodríguez que «Es como una «animación» que recrea, fugitivamente, lo que nos sobrecoge y nos anima, y nos pule, y nos mejora». La «celebración», como antes la «claridad» o la «alianza y la condena»son actitudes complejas, abiertas a la propia complejidad de la realidad y de la vida y a su relación con la subjetividad del poeta, también modulada en diferentes grados. Así, es «conocimiento» y «remordimiento» y «servidumbre», como si asistir a la manifestación de la realidad y de la vida, del «destino humano con todos sus adjetivos», participar de él, contrajera un saber alto y ennoblecedor ( «saber es mejorar $\left.{ }^{8} »\right)$, pero, al mismo tiempo oneroso, culpable y deudor. Como nota Dionisio Cañas (1988: 86), la celebración se produce cuando el poeta logra los instantes de unión y comunión con la unidad y la esencia de las cosas y consigue atraparlos en una formulación poética adecuada

\subsection{La poesía como «participación»}

Una de las definiciones más completas de poesía que ofreció Claudio Rodríguez es la siguiente:

\footnotetext{
${ }^{7}$ «Puedo leer un poema de tema horroroso, macabro, horrible; un poema sobre la carroña, el cuerpo humano en descomposición. Uno lee el poema y le produce placer, una sensación de placer. Uno ve a un hombre crucificado y se aterra, pero ve el pintado por Velázquez y le produce una sensación casi de alegría. A eso me refiero. El sustrato de la poesía es el festejar». (1995: 66).

${ }^{8}$ Como señalaba más arriba, en alguna ocasión aludió el poeta (si bien, de pasada) a la «mejora» que produce la celebración, entendiendo que la escritura revitaliza aquello que está marchito; fenómeno que parece aplicar al proceso creativo, en el sentido de aportarle concreción y sabiduría. (1985: 23).
} 
Si la poesía, entre otras cosas, como he escrito ya, es una búsqueda, una participación entre la realidad y la experiencia poética de ella a través del lenguaje, claro está que cada poema es como una especie de acoso para lograr dichos fines. [...] la realidad y el lenguaje pueden asumir distintas vibraciones, muy variadas aproximaciones, gamas que han de establecer el proceso creador. En el fondo, se trata de la aventura entre la intimidad y la realidad. [...] el lenguaje en poesía no es tan sólo un vehículo para expresar sentimientos, emociones, intuiciones, etc., sino consiste, sobre todo, en la calidad del espíritu expresado, en su 'actuación' y su conformación en el texto. (Rodríguez, 1985: $11^{9}$ ).

Como puede constatarse, esta definición, sobre la que se asienta buena parte de su poética, se revela compleja y algo alejada de la claritas, por cuanto intenta verbalizar un proceso en el que el propio poeta ve muy estrechamente imbricados a sus componentes. También podría tratarse de una decisión del poeta de trasladar al ensayo una forma de escritura propia de su creación poética; un poeta que «no es un razonador, sino un cantor. En su pensamiento está su canto, y viceversa». (Rodríguez, 20041: 217).

Claudio Rodríguez entiende la poesía como «una búsqueda, una participación entre la realidad y la experiencia poética de ella a través del lenguaje». La yuxtaposición de los sustantivos «búsqueda»y «participación», tiende a aproximarlos en un intento, de raíz poética, de que intercambien algunos de sus rasgos semánticos, por ósmosis: así, la búsqueda tendría como instrumento la participación del indagador, y la participación estaría orientada hacia la indagación. Además, esa yuxtaposición permite al autor no precisar el complemento de búsqueda: una búsqueda ¿de qué?

Esta búsqueda participativa — si se me permite denominarla así- es llevada a cabo por el poeta, desde su propia experiencia poética; pero de nuevo, la noción es imprecisa, ambigua, porque ¿qué es lo que se ha de entender por «experiencia poética». Esta búsqueda participativa se ejerce sobre o con la realidad, noción compleja donde las haya ${ }^{10}$. Y la ambigüedad, imprecisión o plurisignificación se acrecientan al pretender la participación entre dos actores, el poeta y la realidad, siendo así que este último carece (en principio) del rasgo semántico «+ animado».

El poema, entonces, es, para Claudio Rodríguez, «como una especie de acoso para lograr dichos fines», es decir, la búsqueda y la participación a través del lenguaje (con la finalidad última de conocer), o mejor, dentro del

${ }^{9}$ Esta definición reelabora otra anterior a la que alude Dionisio Cañas (1988: 86), que me interesa presentar, porque aporta un rasgo esclarecedor para la comprensión de esta poética: «Esta participación —dice Claudio Rodríguez- es un modo peculiar de conocer».

${ }^{10}$ También, entre otros muchos, Jaime Siles vincula realidad y lenguaje en el acto de poetizar, en su aportación a El último tercio del siglo: «I. Poetizar es un acto de Realidad y de Lenguaje: transformar los nombres hasta el sustrato primigenio, indagar tras el concepto originario, pulsar el Ser desde lo uno hasta lo múltiple, devolver la realidad a la Realidad (1974)». (1998: 499). 
lenguaje porque, como nota con agudeza Lanz (2011: 93), el poeta cambió en el 1992 aquella formulación por ésta. La forma de expresión, nuevamente, se aleja de la denotación para decantarse por la sugerencia: «una especie de», necesita mayor precisión, mientras que «acoso» metaforiza la función del poema, dotándolo, de nuevo, del rasgo '+animado'. Continúa Claudio Rodríguez afirmando que «La realidad y el lenguaje pueden asumir distintas vibraciones, muy variadas aproximaciones, gamas que han de establecer el proceso creador»y, de nuevo, la expresión es tan sugerente como imprecisa, por la licencia poética de personificación con que se entiende el comportamiento de los dos componentes de la relación, realidad y lenguaje; pero, además, porque se ha cambiado el orden de los intervinientes en el proceso poético y, con ello, su función. En efecto: el comienzo de la definición parecía adjudicar al lenguaje la labor activa de hacer aflorar lo que surgiera de la relación entre la realidad y la experiencia poética de ella; mientras que ahora no se menciona la experiencia poética y se considera en primer plano, en cambio, la relación entre realidad y lenguaje, de nuevo, entendidos ambos y su relación en su complejidad, dinamismo e inestabilidad. Ahora no es la experiencia poética de la realidad, auxiliada o vehiculada por el lenguaje, la que da lugar al poema (que no es algo acabado o estático o definitivo..., sino que es un intento, parte del dinamismo de la búsqueda y la indagación), sino que el protagonismo activo pasa, sin aviso, a esas «vibraciones, variadas aproximaciones y gamas» que (tal como está redactada la frase) son las que se ofrecen, afectan y guían al «proceso creador», cuya tarea — cabría entender, entonces- es iluminar esos aspectos de la realidad y el lenguaje y sus relaciones.

El resto de la definición brilla por y adolece de los mismos rasgos. Cuando parece que el poeta va a clarificar los términos de reflexión ( «En el fondo se trata de la aventura entre la realidad y la intimidad»), introduce una cita de Leonardo da Vinci sobre la carencia del alma de las cosas fingidas en la pintura, que no parece atañer al núcleo de la cuestión y que, además, no tiene desarrollo ni explicación convenientes, por una decisión del autor difícil de comprender («No es momento de entrar a fondo en estas cuestiones»), ya que el lector siente que sí es el momento, que ese es, justamente, el momento de abundar y ahondar en cómo se coteja poéticamente la realidad desde una conciencia poética, atrayendo hacia el interior subjetivo los objetos y los seres y metamorfoseándolos para manifestar el mito personal propio.

La definición se completa y cierra con otra consideración poco clara sobre el lenguaje en poesía, que Claudio ve más allá de su función de mero vehículo de transmisión de lo experimentado por el poeta, y no queda claro cómo lo liga al «espíritu» del poeta, ya que, en principio, cuanto dice («sino que consiste, sobre todo, en la calidad del espíritu expresado, en su 'actuación' y su conformación en el texto») podría considerarse como una formulación equivalente de aquello que se decía en la primera parte de la propues- 
ta («no es tan sólo un vehículo para expresar sentimientos, emociones, intuiciones»). Pero este es un asunto sobre el que volveremos más adelante.

Lo que va quedando de manifiesto es que Claudio Rodríguez concibe la poesía como energeia, como proceso, no como ergon o resultado o producto del proceso. Esta concepción dinámica, además, afecta a todos los componentes que intervienen, que son vistos y entendidos en su actividad, inestabilidad y complejidad, y al propio resultado del proceso, al poema, que se entiende como estadio o momento de una búsqueda y participación, como un intento. Claudio Rodríguez tiene claro que «En poesía lo que se conoce está actuando en el poema; el proceso del conocer poético no está fuera de las palabras del poema» (en Cañas, 1988: 90) ${ }^{11}$.

Abundó Claudio Rodríguez en la noción de «participación» al hilo de unas consideraciones sobre la condición «imaginativa, emocionante y sabia» del proceso creador, al que entiende como «una aspiración hacia un resplandor definitivo, hacia la participación cierta». ¿Cabría entender, entonces, «participación», como revelación o como participación de lo ideal? ¿La revelación es revelación de la realidad, no de ninguna esencia extraña, o de la Idea, o de Dios, como planteábamos al reflexionar sobre «don» y «ebriedad» ${ }^{12}$ ? Los versos «¿Es que voy a vivir después de tanta / revelación?», de «Manuscrito de una revelación», en Casi una leyenda (1991), remiten, en una anáfora dilatada, en una cita intertextual, al poema VIII de Don de la ebriedad, que cierra el poemario: «Cómo veo los árboles ahora. [...] Y a los campos, al mar, a las montañas, / muy por encima de su clara forma / los veo. ¿Qué me han hecho en la mirada? / ¿Es que voy a morir? [...] / ¿Es que voy a vivir? ¿Tan pronto acaba / la ebriedad?»

\subsection{La «contemplación viva»}

La noción de «participación» — como se ha podido ver- se asienta en la dialéctica entre lo interior y lo exterior, entre la realidad física y la interioridad del poeta, en la que se activan o actúan la emoción, la intuición y la imaginación, por efecto de esa propia realidad, de su «resina», dirá. Añade ahora el poeta la noción de «contemplación viva», para explicar el proceso; noción que relaciona con la Filosofía de las formas simbólicas de Cassirer y su idea sobre la capacidad del arte más elevado para captar lo esencial en lo individual.

Esta noción de «contemplación viva» aparece dominando lo que Rodríguez denomina «el segundo peldaño» de su poesía, el que sigue a la etapa de exal-

\footnotetext{
${ }^{11}$ Sobre la noción y el hecho de esta «participación» fundante, creadora, y cognoscitiva volvió Claudio Rodríguez en 1992 con un planteamiento similar (Rodríguez, 2004h: 131).

${ }^{12}$ Bourne (1984 y 1987) filia este componente de la poética de Claudio Rodríguez a Plotino.
} 
tación por y ante la existencia, que se daba en sus dos primeros poemarios. Se trata de configurar poéticamente las lindes entre lo interior del poeta y lo exterior, mitigado ya el entusiasmo embriagador, y es en ello donde interviene la «contemplación viva». Claudio Rodríguez invoca en sus escritos teóricos a Plotino (Bourne, 1984, Carbajosa, 2011) y su noción de «contemplación» creativa (Rodríguez, 2004h: 132), pero advierte que su platonismo lleva justamente a las antípodas de lo que considera que se produce en la poesía: la potencia con que la contemplación hace presente el objeto contemplado (Rodríguez, 2004d: 104-105).

De nuevo, Claudio Rodríguez aborda esta noción desde la complejidad y la sugerencia («¿transfiguración, creencia? ${ }^{13} »$, se pregunta), yuxtaponiendo dos términos próximos pero dispares y adjudicables, además, al ámbito religioso. Pero en esta ocasión el poeta sí abunda en ello, y lo hace desde planteamientos propios de la poética romántica y postromántica, o coincidentes con ellos. La relación entre la sensibilidad del poeta y la realidad exige la despersonalización del poeta ( «El poeta necesita, aunque no lo sepa, renunciar a su personalidad y, desde luego, a su originalidad»), como también propugnaba Keats (a quien cita Claudio Rodríguez), quien lejos del tópico romántico de la individualidad irreductible, veía al poeta como el ser capaz de encarnar en sí cualquier realidad, como repetirá más tarde Baudelaire en su Esplín de París.

Tras la despersonalización, el poeta —entiende Claudio Rodríguez- está en disposición de responder a su tendencia a «entrañarse», a «identificarse» con el objeto de su contemplación, con la finalidad de «renacer en él», de «reconocerse en él». Con ello, Claudio vuelve a dar un quiebro brusco a su exposición: todo el proceso puede tener como finalidad inmediata el desvelamiento de la realidad, pero la finalidad última busca al propio poeta (y al lector tras él) ${ }^{14}$.

Esta es la labor poética, en la que el poeta queda renovado por la comunión con el objeto contemplado «en el proceso poético, en la aventura de la visión, de la inspiración armoniosa». (Rodríguez, 2004h: 134 y 2004l: 220) ${ }^{15}$.

${ }^{13}$ «Amor», dirá en otro texto donde retoma este asunto y trae a colación a San Juan de la Cruz y los versos del Cántico espiritual donde la amada invoca la presencia y la figura como únicos remedios para la pena de amor. (Rodríguez, 2004k: 193-196).

${ }^{14}$ Esta noción recuerda o sigue de cerca lo manifestado por Hegel sobre la inspiración (1989: 209), pero el filósofo apunta hacia la condición de posibilidad de la poetización, no al efecto que se consiga con ella; además, Claudio Rodríguez reserva este término para otro componente poético, como veremos más adelante. Por otro lado, la forma de explicación de este proceso recuerda vivamente a las paradojas con que los místicos ofrecen un acercamiento a la etapa unitiva, o los profanos, al amor y la experiencia sexual: El «Se entrega y huye, se pierde y se encuentra a la vez, como renovado en el proceso poético, en la aventura de la visión, de la inspiración armoniosa», trae a la memoria las palabras de la Esposa en el Cántico espiritual: «diréis que me he perdido, / que andando enamorada / me hice perdidiza y fui ganada».

${ }^{15}$ Claudio Rodríguez volvió a emplear estos conceptos (incluso a utilizar frases idénticas), para explicar la noción de poesía de Jorge Guillén (Rodríguez, 2004d: 104-105). 
Subraya García Berrio con acierto la importancia de la «metamorfosis» de los objetos de la realidad, en esta relación cognoscitiva y poética subjetivo-objetiva de la obra de Claudio Rodríguez. Modificación que se corresponde y complementa con la disposición del poeta a fundirse e identificarse con el objeto contemplado ${ }^{16}$, en el proceso de «contemplación viva» (García Berrio, 1998: 441 y 549).

En El vuelo de la celebración hay un poema titulado, justamente, así, «La contemplación viva», en el que el poeta capta el paso fugaz de una transeúnte (como Baudelaire en «À une passeante», de Les fleurs du mal), y entra en posesión del secreto de la mujer por la mirada, «a través de la más / arriesgada y entera / aventura: la contemplación viva». Como ocurría en el poeta francés, donde el encuentro de las miradas y el conocimiento se resolvían en disgusto del yo poético por la imposibilidad de comunicación amorosa («Ô toi que j'eusse aimée, ô toi qui le savais!»), en Claudio Rodríguez también es constatación de «la intensidad de este momento» y con él de «la fertilidad de lo que huye / y lo que me destruye». Lo que muestra el poema, en suma, es el poder de la poesía para rebasar la corteza de las cosas, para ir más allá de la apariencia cotidiana que oculta una realidad más honda, hasta llegar al ser. La mirada es, entonces, el acto y el símbolo de la intelección poética.

Pero el poemario donde encuentra mayor alojo esta «contemplación viva» es Alianza y condena. Hay en él —como dijimos más arriba- una nueva mirada, consciente y activa, ocupada ya en el misterio de la realidad multiforme y plural y de los hombres, atenta a las dificultades y obstáculos que impiden el contacto con ellos y su conocimiento (las cáscaras, la ropa, los envoltorios, los caparazones y corazas...). Lejos ya los anhelos de revelación de la unidad verdadera y sin la ayuda de la paradójica iluminación nocturna, el poeta mira ahora con la luz del mediodía y se contenta, se satisface con la comprobación de la multiplicidad y la acepta: su tarea ahora, cognoscitiva, será la de aplicar la mirada a la realidad para limpiarla de la ganga que oculta su verdadera esencia. Del símbolo primordial de Conjuros, de la uva-corazón estrujados (con violencia y dolor) para obtener el zumo de la verdad fraterna y solidaria, pasamos ahora a símbolos convergentes de la intimidad y la protección, como la cama del dormitorio familiar de la infancia o de la almendra del fruto; pero son símbolos que aparecen amenazados y hasta violados. La experiencia erótica tampoco arroja revelación cognoscitiva, sino duda sobre su sentido último. Este es, pues, el momento de la «contemplación viva»,

${ }^{16}$ A este respecto, recuerda García Berrio (1998: 441) la declaración del poeta en una entrevista concedida a Curtis Miller (en Anales de Literatura Española Contemporánea), donde decía: «Yo quería penetrar, saber lo que es un árbol y saberlo expresar... Yo quiero convertirme, abandono mi personalidad y quiero convertirme yo en el árbol, en el objeto del poema... Quiero ser yo el árbol». Proceso que — como decía más arriba- hace pensar en las conocidas manifestaciones de Keats sobre la impersonalidad del poeta. 
del empeño en acceder al reducto último de la esencia de las cosas, de los seres y los gestos, o de su sentido, por encima o por debajo de su atractivo mutismo; el momento de la constatación de la imposibilidad de rebasar sus caparazones y de acceder al lugar de la «sutura» $\operatorname{con}$ ellos ${ }^{17} \mathrm{y}$, por tanto, mucho menos a su posesión.

\subsection{La dificultad de la «contemplación viva»}

Son numerosas, y sustantivas, las referencias a la mirada (como hecho físico y trasunto de la labor del conocimiento, al mismo tiempo ${ }^{18}$ ), que pueden hallarse en la poesía de Claudio Rodríguez. En el poema de Conjuros «Con media azumbre de vino», en particular, el poeta exclama: « Meted hoy en los ojos el aliento / del mundo, el resplandor del día! Cuándo / por una sola vez y aquí, enfilando / cielo y tierra, estaremos ciegos. ¡Tardes, / mañanas, noches, todo, árboles, senderos, / cegadme! / El sol no importa, las lejanas / estrellas... ¡Quiero ver, oh, quiero veros! / [...] Ved: ya los sentidos / son una luz hacia lo verdadero». (Rodríguez, 1998: 134-135). Se trata de una acción de mirar consciente $^{19}$ en la que ya no hay raptos ni éxtasis y en la que los ojos se asombran serenamente ante la naturaleza revelada; entonces, incapaces de poseer lo visto, son invitados a penetrar en ello, como se expresaba en el final de Don de la ebriedad: «el aire de hoy tiene su cántico. / ¡Si lo oyeseis! Y el sol, el fuego, el agua, / cómo dan posesión a estos mis ojos» (Cañas, 1984). Hay otro aspecto que hace compleja esta contemplación poética —al que ya me he referido más arriba-, y es el hecho de que se contempla con todo el cuerpo, que - como percibió Vicente Aleixandre- hay (en los primeros poemarios de Claudio Rodríguez) contemplación y «respiración»: una disposición ascensional «en la contemplación de la naturaleza», y hay también tendencia a «una embriaguez de totalidad respirada» (en Cañas, 1988: 100). Notó ya Aleixandre, tempranamente, el que iba a ir constituyéndose en uno de los símbolos más sustantivos de la indagación poética de Claudio Rodríguez, el de la respiración (cercano al del viento), que vincula íntimamente interior y exterior, la subjetividad del que con-

17 «Dentro del ámbito doloroso de la separación se mueve la vida y la obra del poeta: separado de los padres por la falta de amor que éstos le muestran; separado de la inocencia por la experiencia de la vida; separado de la pureza espiritual por el conocimiento intelectual; separado del hombre natural por su educación burguesa y semiurbana. Sólo un esfuerzo emocionadamente poético, casi de orden religioso, religa a Claudio Rodríguez con todo lo antes mencionado. Su poesía es un intento de encontrar esa sutura entre el hombre y lo esencial del mundo» (Cañas, 1988: 26); ver también Jiménez, 1972: 151-152 y Prieto de Paula, 1993: 27-34.

${ }^{18}$ No en vano Aristóteles y el Tomismo consideraban a la vista como el superior y más «intelectual» de los sentidos, y establecían semejanzas entre vista e intelecto.

${ }^{19}$ Lejos de la falta de dueño surreal a la que alude Silver (1985). 
templa y la objetividad de lo contemplado; símbolo, acción o gesto que irá ganando peso en esta poesía hasta convertirse en capital en El vuelo de la celebración (García Berrio, 1998: 659).

La acción de contemplar, por tanto, no es fácil, pero no sólo por esta relación entre la mirada y su objeto, sino también por lo complejo y lo variable de ese mismo objeto contemplado, en cuya esencia se quiere penetrar. El poeta lo expresó en sus reflexiones escritas y también en sus poemas; sobre todo, en el titulado «Sin adiós» (de El vuelo de la celebración), donde va pormenorizando las diferencias que se producen en las cosas y en el cuerpo amado («El movimiento curvo de las olas, / por la mañana, tan distinto al nocturno / tan semejante al de los sembrados, / se van entrando en / el rumor misterioso de tu cuerpo»), para concluir comparando la actividad de soñar con la del contemplar: «El soñar es sencillo, pero no el contemplar».

Y un aspecto más que hace problemática la contemplación y la experiencia poética tiene que ver con la complejidad y tendencia a la totalidad vital de la experiencia. Se planteaba el poeta «un grave problema poético: ¿La experiencia es concreta?»y, aunque no lo llegaba a responder en ese momento, una reflexión hecha en otro lugar viene a contestarlo en parte:

Mas la contemplación poética es un merodeo, una especie de acoso a la totalidad de la experiencia, a su recóndita unidad a través de la multiplicidad, de la contradicción, de la inefabilidad de las sensaciones. Un poema, por lo tanto, no nace tan sólo de una «visión actual», de una experiencia concreta, sino de la aparición de dicha experiencia creándose en contacto con la vivencia total del poeta». (Rodríguez, 2004k: 194; ver también Rodríguez, 2003: 13).

\subsection{La contemplación poética y la materia}

La «contemplación viva» se ejerce sobre lo que Claudio Rodríguez denomina la «materia», entidad que será considerada como uno de los ejes de su poesía (Rodríguez, 20041: 219). La materia es entendida en sentido físico y como poseedora de un valor en sí misma o de un misterio valioso que hay que desentrañar, porque en ello nos va la revelación de la verdad y el conocimiento de nosotros mismos, como advertían Santa Teresa o Rilke (a quienes tiene muy presentes y cita Claudio Rodríguez), o Dámaso Alonso (1969) o Antonio Colinas ${ }^{20}$, entre sus próximos. Esta materia de ningún modo es

\footnotetext{
${ }^{20}$ Quien declara: «...Creo con Rimbaud que mi interés no va más allá del que siento por la tierra y por las piedras. La tierra y las piedras como expresión primera y llena de símbolos a la que dirigir nuestras preguntas». (en Moral, 1980: 222). Y en otro lugar: «La poesía es para mí una vía de conocimiento. Es decir, un medio para interpretar y valorar la realidad. Pero no sólo esa realidad aparente que los ojos ven, sino lo que yo he llamado en otros momentos una realidad trascendida (en El último tercio del siglo, 1998: 217).
} 
estática ni inerte, sino que despliega su actividad («lejos de los hombres»), y se desplaza y transfigura, viva y dinámica («Nocturno de la casa ida», de Casi una leyenda).

Se afilia el poeta en sus consideraciones a las corrientes filosóficas, linguiísticas y, desde luego, poéticas, que problematizan los vínculos entre significante y significado y las relaciones entre el signo y la realidad que intenta designar («como escribe Rilke: "atreveos a decir lo que llamáis manzana"»). Por ello, se hace imprescindible interpretar la materia, su forma, su actividad.

No lo señala el poeta, a este respecto, pero se observa en varios pasajes de su poesía una actividad del que contempla, adentrando su pensamiento en lo interior de lo contemplado ( «va el contenido ardor del pensamiento / filtrándose en las cosas, entreabriéndolas, / para dejar su resplandor y luego / darle una nueva claridad en ellas». (III, Don de la ebriedad) ${ }^{21}$. Pero, en correspondencia, el hecho de la contemplación, el llenarse de la cosa contemplada, puede producir en el poeta un «deslumbramiento» auto-cognoscitivo. Se trata de «fugaces momentos inefables» que el autor no duda en entender y denominar como «inspiración», «enajenación luminosa, misteriosa y cierta» que despierta y asombra al poeta y lo lleva a la creación (Rodríguez, 2004h: 136 ${ }^{22}$.

\subsection{El acto creador y el poema: la «palabra verdadera»}

La «participación», la «contemplación viva» se resuelven y sustancian en la poesía para Claudio Rodríguez en asunto de lenguaje, en «expresión viva». Es la palabra, dirá, la que excava un cauce en la creatividad del poeta (Ro-

${ }^{21} \mathrm{O}$ en «Un viento» de El vuelo de la celebración: «Ven / conocimiento mío, a través de / tanta materia deslumbrada por tu honda/ gracia».

${ }^{22}$ Alguna cercanía hay entre esta concepción de la inspiración y la que sustenta Vicente Aleixandre, al considerarla como «un hervor en el reducido recinto del corazón de fuerzas innumerables, concentradas finalmente como una sola espada atravesando de dentro a fuera el pecho del inspirado», espada cuya empuñadura se halla para Aleixandre en el propio centro de la tierra. Dentro de la Poética del Imaginario, Gastón Bachelard desarrolla un programa que moviliza también nociones como «materia» o «contemplación», aunque es de signo distinto al de Claudio Rodríguez. Considera el filósofo francés lo que denomina «la meditación de la materia», como componente básico y esencial del hecho poético; pero su investigación tiene como objeto a la imaginación y el ámbito específico al que atiende es la «región superficial donde se mezclan el consciente y el inconsciente» (1978: 179), además de entender que la ensoñación material precede a la contemplación ( «Se sueña antes de contemplar») (1978: 12). La materia a la que se refiere Bachelard, en fin, es materia elemental, en el sentido presocrático, sentido ajeno al pensamiento de Claudio Rodríguez ( «Nuestra tarea en este libro es precisamente probar que algunas materias nos trasladan su potencia onírica, una especie de solidez poética que da unidad a los verdaderos poemas. $\mathrm{Si}$ las cosas ponen en orden nuestras ideas, las materias elementales ponen en orden nuestros sueños». (1978: 204). 
dríguez, 2004h: 134), y la que, surgida ex profeso en el proceso poético, será inseparable de él (Rodríguez, 20041: 217), condición que explica su singularidad y su feracidad semántica ${ }^{23}$. La razón de ser de la contemplación poética es llegar a ser, a traducirse en «palabra verdadera», cualidad que Claudio Rodríguez trata de explicar citando a Goethe: «Si conozco la relación conmigo mismo y con el mundo exterior, llamo a eso verdad». El medio, pues, para lograr tal verdad es la palabra». (Rodríguez, 2004k: 193-196).

El poema — como no puede ser de otro modo, en una concepción dinámica y compleja del proceso poético, del acto creador - no se considera como resultado, producto final, parte última, cosecha obtenida, algo acabado e inerte, el producto final de un destilado o la plasmación de una experiencia, sino como la parte culminante del proceso en su dinamismo (al que el poeta aporta todo lo que es ${ }^{24}$ ), como lugar en que se produce la iluminación cognoscitiva, como lugar y momento de la «inspiración»: no hay una iluminación previa al poema, que luego se pasa a él en palabras, sino que el poema es el lugar, el espacio en que el poeta tantea la revelación en su labor con la palabra, el instante en que ésta se produce. Es posible que esa revelación o un atisbo de ella se haya producido ya en un momento anterior, pero el poema no relata algo pasado y hecho, sino que, retomando — si es preciso- el recuerdo de la iluminación pasada o afrontando la sobrevenida en el momento, se aplica a la tarea de configurarla y darla a luz.

En esta concepción Claudio Rodríguez viene a coincidir con José Ángel Valente, quien sustenta también que «el conocimiento se produce en el mismo proceso creador» y que en ello consiste lo que se denomina la creación poética (1994: 21 y 22) 25 $^{2}$ Por ello, ambos también coinciden en una importante consecuencia: la poesía ha de ser entendida como un medio de conoci-

${ }^{23}$ Como sostiene Carlos Bousoño, en su definición: «Poesía: dar la impresión de que palabras responsables se han alzado a una plenitud o saturación de sus significados». (Texto puesto al frente de «En el poema», de El martillo en el yunque, 1996; en Bousoño 1998: $824)$.

${ }^{24}$ «Como el poema, que no es tan sólo la expresión de un suceso concreto sino que es su aparición amasándose con la inteligencia y con la sensibilidad del poeta, con su manera de vivir en todos los sentidos». (Rodríguez, 2004h: 135). Una forma similar de concebir el acto creador la veía Claudio Rodríguez en Jorge Guillén: «En resumen, «la expresión constituye una conquista espiritual que, en último término, será creación estética. Vida con espíritu más forma dentro de una sola unidad indivisible: ¿no será esto la poesía?», se pregunta Jorge Guillén [...]» (Rodríguez, 2004d: 107).

${ }^{25}$ Precisa algo más José Ángel Valente el proceso de conformación del poema de lo que lo hace Claudio Rodríguez, al hablar del «avance por tanteo»: «Este avance por tanteo es característico de la conformación del poema, de todo poema, cuyos elementos a medida que van emergiendo van corrigiéndose a sí mismos (a veces eliminándose) en busca de la precisa formulación de su objeto, que ninguno de ellos por sí mismo encierra y que no puede encontrarse más que en el poema como estructura unitaria y superior a todos ellos». (Valente, 1994: 23). 
miento exclusivo para aprehender algunos aspectos de la experiencia (dirá Valente), o para acceder a la materia (dirá Rodríguez), conocimiento que no podría adquirirse ni expresarse, si no fuera mediante el lenguaje poético. Se entiende con facilidad, entonces, la enorme responsabilidad que recae en el lenguaje en un uso poético de este tipo, que no se aplica a la descripción más o menos ajustada de superficies o sentimientos sencillos, sino que afronta la indagación de honduras de notable espesor y complejidad (Siles, 1981; Lanz, 1995, 1996; Trabado, 2009), con un admirable esfuerzo por evitar ser críptico (Sala Valldaura, 1978).

La concepción de Claudio Rodríguez sobre el lenguaje poético, sobre la lengua hecha en la poesía, es, nuevamente, compleja. De forma general, podría decirse que su poética, en este aspecto, viene a enlazar con concepciones de raíz romántica, como se ve también en Valente (1994: 20 y 22), quien ya había recurrido, de forma explícita, a la concepción de Humboldt sobre el lenguaje, considerado como medio específico de conocimiento del mundo. Pero, hecha esta salvedad, Claudio Rodríguez no aborda de forma nítida o cabal la condición de la lengua poética, del lenguaje utilizado de forma especial en el ámbito poético. Al hilo de unas consideraciones sobre la poesía de José Hierro sugiere que «la poesía [...] es la palabra necesaria y misteriosa y clara». (Rodríguez, 2004i: 158), algo que necesitaría de mayor abundamiento y explicación, aunque pueda intuirse su sentido. Tampoco hay mayor desarrollo en otra consideración sugerente que el poeta hacía al hilo (o en el fragor) de su exposición sobre la «participación» y la «contemplación viva». En ella afirmaba que «La palabra se alza o susurra hacia lo que he llamado la contemplación viva», sin que el lector llegue a alcanzar cuál sea el significado y la función que cumple en ese acercamiento. Tampoco encuentra desenvolvimiento exterior la consideración de la correspondencia entre la intensidad de la vivencia y la de la expresión con que se funde: (Rodríguez, 2004h: 134 y 20041: 220).

El poeta señaló que trataba de que el lenguaje de sus poemas fuera un lenguaje «vivo», «distinto del lenguaje escrito», sin querer decir con ello que fuera un lenguaje «popular» (1985: 17). Podría aventurarse que detrás de esta consideración, hecha al paso de un comentario, pudiera estar la posición poética de Wordsworth, cuando exponía su decisión de hacer poesía con las situaciones y el lenguaje común, por considerarlo «más permanente y mucho más filosófico» que el que suelen utilizar los poetas, nacido de su capricho y no del acervo común ${ }^{26}$. Lo que sí se percibe en el contacto con su poesía es que Claudio Rodríguez manifiesta una creencia intuitiva en una concepción casi naturalista del lenguaje, al sentir que las palabras cotidianas, las usuales,

\footnotetext{
${ }^{26}$ Postura poética a la que se aproximaba Gil de Biedma, quien entendía que la poesía se nutre de situaciones cotidianas, lo que anima a expresarlas en ella con el lenguaje conversacional.
} 
las más sencillas, son aquellas que se hallan más cerca de las cosas que designan, razón por la cual son las más adecuadas para acceder a la esencia de las cosas, para conocerlas y salvarlas ${ }^{27}$. Prieto de Paula habla con acierto de «primitivismo léxico» para referirse a la «virginidad semántica conseguida mediante la reducción de las distancias entre cosas y palabra que a ella se refiere». y a cómo la palabra del poeta deja la impresión de estrenarse en el poema. (1993: 61).

\subsection{El ritmo}

En lo que sí abundó Claudio Rodríguez, por el contrario, fue en la importancia sustancial del ritmo para la poesía. Subraya el poeta zamorano la importancia generadora de la palabra en el poema. La hemos visto amasándose con la emoción en la contemplación viva, sustanciándola, y podría verse también en su dimensión creativa, mágica en los juegos de los niños, donde destaca su valor fónico-afectivo. (Rodríguez, 2004a). En su temprano estudio sobre el ritmo en Rimbaud, Claudio Rodríguez pasa a referirse a la palabra en cuanto palabra por su condición fónica (como querían los formalistas rusos): la palabra es sentida en el poema, antes que nada, en una materialidad que, mediante el ritmo, producirá la musicalidad: y el ritmo «es lo más importante», dirá. Pero Claudio Rodríguez va más lejos, al señalar la dependencia del sonido que el sentido tiene en el poema: «De tal manera que es la palabra la creadora del poema intrínsecamente; tenga o no un periodo de posibilidad lógica, es indudable que tiene posibilidad rítmica. Y el ritmo, la palabra como sonido, es lo que nos hace inteligible la idea, lo que le da relieve. La palabra "significa" en la medida que "suena"». (Rodríguez, 2004b: 91).

El ritmo, entendido como «ritmo personal», es, para Claudio Rodríguez «lo más importante» (Rodríguez, 2004m: 231), es «esencial» (Rodríguez, 2004i: 156), y sin «ritmo personal no hay poesía» (Rodríguez, 2004d: 106). Pero, por supuesto, no se está refiriendo sólo a la musicalidad externa, ya que ésta está supeditada al ritmo interior y encuentra en él su razón de ser (García Jambrina, 1987). No se aplica el poeta a explicar con claridad qué haya de entenderse por ese ritmo interior personal, cuando habla de él en la poesía de Jorge Guillén, Alberti (Rodríguez, 2004f: 123) o José Hierro (Rodríguez, 2004i: 156), y subraya su importancia; pero, al estudiar la poesía de Gerardo Diego, sí precisa algo más, cuando señala cómo los componentes formales de su poesía «se conjugan con los estímulos interiores del pensamiento y de la emoción viva» (Rodríguez, 2004e: 112). Se trata de la «calidad del espíritu expresado»; como dice en las

${ }^{27}$ «Lo que a mí me interesa — declaraba el poeta- es la salvación de la materia, la salvación de la realidad. No en el sentido religioso sino el salvar las cosas existentes, el elevarlas a cierto plano en el cual estén más claras, más limpias, más puras». (en Cañas, 1988: 91). 
consideraciones que hace sobre la poesía de César Vallejo, lo que explica su singularidad es «la calidad del alma que busca una nueva expresión. No hacia fuera, sino hacia dentro» (Rodríguez, 2004c: 98) ${ }^{28}$.

Ese ritmo, se nos dice, es «un fermento», «implica musicalidad, armonía, concierto, desconcierto» y «reproduce el movimiento interior del poeta», y es el que orienta las decisiones que se hayan de tomar en el poema en todos sus planos. (Rodríguez, 2004m: 231). Podría aventurarse que Claudio Rodríguez sigue de cerca en esta concepción a Paul Valéry (1948), cuyas apreciaciones sobre la sensibilidad poética de Mallarmé y el lugar que ocupa en ella la palabra son bien conocidas, lo mismo que ocurre en las que hace sobre su propia obra y la interdependencia de la forma y los movimientos interiores de su sensibilidad, motivados y conducidos en ocasiones por una musicalidad interna que rige la configuración del poema o por un ritmo externo que va encontrando poco a poco un sentido interno.

\section{BIBLIOGRAFÍA CITADA}

Alonso, Dámaso (1969). Poemas escogidos. Madrid: Gredos.

Alonso, Dámaso (1976). Poesía española, ensayo de métodos y límites estilísticos. Madrid: Gredos.

Aristóteles, Poética (1994). Texto, noticia preliminar, traducción y notas de José Alsina Clota. Barcelona: Icaria.

Asís, María Dolores de (1977). «Claudio Rodríguez (1934). «La realidad trascendida»», en María Dolores de Asís (ed.), Antología de poetas españoles contemporáneos. Vol. 2: 1936-1970. Madrid: Narcea, pp. 189-190.

Bachelard, Gaston (1978). El agua y los sueños. México: F.C.E.

Baudelaire, Charles (1976). «Richard Wagner et Tannhäuser à Paris», en Charles Baudelaire, Oeuvres completes, II, Texte établi, présenté et annoté par Claude Pichois. Paris: Gallimard, pp. 779-815.

Baudelaire, Charles (1995). Las flores del mal. Edición bilingüe de Alain Verjat y Luis Martínez de Merlo. Madrid: Cátedra.

\footnotetext{
${ }^{28}$ Así lo entiende García Berrio, junto al poeta, en su importante y sugestivo estudio de «crítica convivida», al señalar «el protagonismo generador del ritmo en la inspiración de poetas como Claudio Rodríguez y sus modelos, desde Schiller a Rimbaud o Jorge Guillén; con la conocida descripción de este último del impulso primario «hacia el poema» como sentimiento de «ritmo desenlazado». (García Berrio, 1998: 32; ver también las pp. 453-454 para una reflexión sobre la importancia fundamental para los poetas de este «impulso preformalizado: esas líneas acústicas de ritmo, el espectro espacial de una estructura del poema, la necesidad atractiva de un quiebro de la linealidad - igramatical, retórica? - en el impulso argumentativo, etc....etc... En suma, índices dispositivos del impulso global poético previos frecuentemente a las imágenes semantizadas de la inventio»; y en la 455, donde vuelve a subrayar: «este factor absoluto del ritmo es sin duda lo esencial de la forma poética, fluido de cruce para la ósmosis de la forma interior y las formas externas poemáticas. Pues por ritmo entiende Claudio el trayecto integral emotivo de los textos, pero también el específico de cada una de las piezas que los componen, de sus unidades armónicas intencionadas»).
} 
Baudelaire, Charles (2009). «Las muchedumbres», en Charles Baudelaire, El spleen de Paris. Edición de Manuel Neila. Sevilla: La Espuela de Plata, pp. 65-67.

Benítez Reyes, Felipe (1996). «La certeza de las dudas. (Tres ensayos sobre la poesía)», en Felipe Benítez Reyes, Paraísos y mundos. Madrid: Hiperión.

Bobes, María del Carmen (1992). «La literatura. La ciencia de la literatura. La crítica de la razón literaria», en Darío Villanueva (ed), Curso de teoría de la literatura. Madrid: Taurus, pp. 19-45.

Bourne, Louis (1984). «Plotino y las hermosas agresiones de Claudio Rodríguez», Libros, 25 , pp. 61-82.

Bourne, Louis (1987). «La alta huella de Plotino en Claudio Rodríguez», Cuadernos de la lechuza, 4-5, s. pag.

Bousoño, Carlos (1971). «La poesía de Claudio Rodríguez», prólogo a Claudio Rodríguez, Poesía (1953-1966). Barcelona: Plaza y Janés, pp. 9-35.

Bousoño, Carlos (1985). Poesía postcontemporánea. Cuatro estudios y una introducción. Madrid: Júcar.

Bousoño, Carlos (1998). El martillo en el yunque, en Carlos Bousoño, Primavera de la muerte. Poesías completas (1945-1998). Barcelona: Tusquets.

Bradford, Carole A. (1979). «Transcendent Reality in the Poetry of Claudio Rodríguez», Journal of Spanish Studies: Twentieth Century. Vol. 7, n. ${ }^{\circ}$ 2, pp. 133-146.

Cano, José Luis (1974). «La poesía de Claudio Rodríguez: de Conjuros a Alianza y Condena», en José Luis Cano, Poesía española contemporánea; las generaciones de postguerra. Madrid: Guadarrama.

Cañas, Dionisio (1984). Poesía y percepción (Francisco Brines, Claudio Rodríguez y José Ángel Valente). Madrid: Hiperión, pp. 81-140.

Cañas, Dionisio (1988). Claudio Rodríguez. Madrid: Júcar, 1988.

Carbajosa, Natalia (2011). «Plotino en la poesía de Claudio Rodríguez y el pensamiento de Kathleen Raine», Campo de Agramante. Homenaje a Claudio Rodríguez 1934-1999, 16, pp. 57-68.

Díez, Luis Mateo (2001). La mano del sueño. (Algunas consideraciones sobre el arte narrativo, la imaginación y la memoria). Discurso de ingreso en la Real Academia Española leído el día 20 de mayo de 2001 en su recepción pública por el Exmo. Sr. Luis Mateo Díez. León.

El último tercio del siglo (1968-1998): antología consultada de la poesía española. Madrid: Visor, 1998.

García Berrio, Antonio (1998). Forma interior. La creación poética de Claudio Rodríguez. Málaga: Ayuntamiento de Málaga.

García Jambrina, Luis M. (1987). «La trayectoria poética de Claudio Rodríguez (1953-1976): análisis del ritmo», Studia Zamorensia. Universidad de Salamanca, 8, pp. 97-118.

García Jambrina, Luis M., ed. (1998). Claudio Rodríguez. Don de la ebriedad. Conjuros. Madrid: Clásicos Castalia.

Hegel, Georg W. F. (1989). Lecciones sobre la estética. Traducción del alemán de Raúl Gabás. Barcelona: Península.

Jiménez, José Olivio (1972). «Hacia la verdad en Alianza y condena, de Claudio Rodríguez», en José Olivio Jiménez, Diez años de poesía española, 1960-1970. Madrid: Ínsula.

Lanz, Juan José (1995). «Claudio Rodríguez y la generación del 50», en J. Paulino Ayuso (ed.), Claudio Rodríguez [Monográfico], Compás de Letras. Madrid: Universidad Complutense de Madrid, 6, junio, pp. 41-65.

Lanz, Juan José (1996). «Claudio Rodríguez en la generación del 50: del conocimiento como participación al lenguaje como celebración y leyenda», Letras de Deusto. XXVI, 70 (enero-marzo), pp. 89-125. 
Lanz, Juan José (2009). «La poesía de Claudio Rodríguez: del conocimiento como participación al lenguaje como celebración y leyenda», en Juan José Lanz (ed.), Las palabras gastadas. Poesía y poetas del medio siglo. Sevilla: Renacimiento, 2009, pp. 231-274.

Lanz, Juan José (2011). «Hilando», de El vuelo de la celebración, o el acontecer del canto», Campo de Agramante. Homenaje a Claudio Rodríguez 1934-1999, 16, pp. 91-104.

Moral, Concepción G. (ed.) (1980). Joven poesía española: antología. Selección de Concepción G. Moral; introducción de Rosa M ${ }^{\mathrm{a}}$ Pereda. Madrid: Cátedra.

Paulino Ayuso, José, ed. (1995). Claudio Rodríguez. [Monográfico], Compás de Letras. Universidad Complutense de Madrid, 6, junio.

Prieto de Paula, Ángel. L. (1993). La llama y la ceniza. Introducción a la poesía de Claudio Rodríguez. Salamanca: Universidad de Salamanca.

Prieto de Paula, Ángel. L. (1995). «Claudio Rodríguez ante la crítica», en J. Paulino Ayuso (ed.), Claudio Rodríguez [Monográfico], Compás de Letras. Madrid: Universidad Complutense de Madrid, 6, junio, pp. 67-78.

Prieto de Paula, Ángel. L. (2011). «El visionario, el contemplativo (El sentido de la evolución en Claudio Rodríguez)», Campo de Agramante. Homenaje a Claudio Rodríguez 1934-1999, 16, pp. 49-56.

Rilke, Reiner $\mathrm{M}^{\mathrm{a}}$ (2010). Cartas a un joven poeta. Madrid: Hiperión.

Rodríguez, Claudio (1983). Desde mis poemas. Don de la ebriedad. Conjuros. Alianza y condena. El vuelo de la celebración. Edición del autor. Madrid: Cátedra.

Rodríguez, Claudio (1985). Reflexiones sobre mi poesía. Madrid: Universidad Autónoma.

Rodríguez, Claudio (1991). Casi una leyenda. Barcelona: Tusquets.

Rodríguez, Claudio (1995). «Lectura comentada de poemas», en Almudena Martínez y Miguel Ángel Muro (eds.), Actas del Seminario de Creación y Teoría literarias, 1994. Logroño.

Rodríguez, Claudio (1998). Don de la ebriedad. Conjuros. Edición de Luis García Jambrina. Madrid: Castalia.

Rodríguez, Claudio (2000). Antología personal. Madrid: Visor.

Rodríguez, Claudio (2003). La voz de Claudio Rodríguez. Poesía en la Residencia. Madrid: Asociación de Amigos de la Residencia de Estudiantes.

Rodríguez, Claudio (2004). La otra palabra. Escritos en prosa. Edición de Fernando Yubero. Barcelona: Tusquets.

Rodríguez, Claudio (2004a). «El elemento mágico en las canciones infantiles de corro castellanas», en C. Rodríguez, La otra palabra. Escritos en prosa. Edición de Fernando Yubero. Barcelona: Tusquets, pp. 29-76.

Rodríguez, Claudio (2004b). «Anotaciones sobre el ritmo en Rimbaud», en C. Rodríguez, La otra palabra. Escritos en prosa. Edición de Fernando Yubero. Barcelona: Tusquets, pp. 77-92.

Rodríguez, Claudio (2004c). «Junto al cuerpo y el alma», en C. Rodríguez, La otra palabra. Escritos en prosa. Edición de Fernando Yubero. Barcelona: Tusquets, pp. 98-99.

Rodríguez, Claudio (2004d). «Unidad y variedad en la obra de Jorge Guillén», en C. Rodríguez, La otra palabra. Escritos en prosa. Edición de Fernando Yubero. Barcelona: Tusquets, pp.100-110).

Rodríguez, Claudio (2004e). «Junto a Gerardo Diego», en C. Rodríguez, La otra palabra. Escritos en prosa. Edición de Fernando Yubero. Barcelona: Tusquets, pp. 111-113.

Rodríguez, Claudio (2004f). «Alberti y la poesía oral», en C. Rodríguez, La otra palabra. Escritos en prosa. Edición de Fernando Yubero. Barcelona: Tusquets, pp. 123-126.

Rodríguez, Claudio (2004g). «Junto a Gabriel Miró», en C. Rodríguez, La otra palabra. Escritos en prosa. Edición de Fernando Yubero. Barcelona: Tusquets, pp. 127-130.

Rodríguez, Claudio (2004h). «Poesía como participación: hacia Miguel Hernández», en C. Rodríguez, La otra palabra. Escritos en prosa. Edición de Fernando Yubero. Barcelona: Tusquets, pp. 131-147. 
Rodríguez, Claudio (2004i). «José Hierro», en C. Rodríguez, La otra palabra. Escritos en prosa. Edición de Fernando Yubero. Barcelona: Tusquets, pp. 156-159.

Rodríguez, Claudio (2004j). «Leopardi», en C. Rodríguez, La otra palabra. Escritos en prosa. Edición de Fernando Yubero. Barcelona: Tusquets, pp. 170-173.

Rodríguez, Claudio (2004k). «Hacia la contemplación poética», en C. Rodríguez, La otra palabra. Escritos en prosa. Edición de Fernando Yubero. Barcelona: Tusquets, pp. 193-196.

Rodríguez, Claudio (20041). «Claudio Rodríguez o la influencia de todo. Entrevista de Federico Campbell», en C. Rodríguez, La otra palabra. Escritos en prosa. Edición de Fernando Yubero. Barcelona: Tusquets, pp. 217-228.

Rodríguez, Claudio (2004m). «Claudio Rodríguez. El hombre no puede ser libre. Entrevista de Juan Carlos Suñén», en C. Rodríguez, La otra palabra. Escritos en prosa. Edición de Fernando Yubero. Barcelona: Tusquets, pp. 229-238.

Sala Valldaura, Josep Ma (1978). «Algunas notas sobre la poesía de Claudio Rodríguez», Cuadernos Hispanoamericanos, 334, pp. 64-75.

Sánchez Santiago, Tomás (2011). «Todo adiós», Campo de Agramante. Homenaje a Claudio Rodríguez 1934-1999, 16, pp. 37-48.

Siles, Jaime (1981). «La palabra fundadora», Quimera, 9-10, pp. 75-77.

Silver, Philip W. (1985). «Claudio Rodríguez o la mirada sin dueño», en Philip W. Silver, La casa de Anteo. Estudios de poética hispánica. Madrid: Taurus, pp. 220-239.

Trabado Cabado, José Manuel (2009). «La escasez suficiente. (Po)ética en la obra de Claudio Rodríguez», en República de las Letras, 112, pp. 65-74.

Valente, José Ángel (1994). «Conocimiento y comunicación», en José Ángel Valente, Las palabras de la tribu. Barcelona: Tusquets, pp. 19-25.

Valente, José Ángel (1994). «Tendencia y estilo», en José Ángel Valente, Las palabras de la tribu. Barcelona: Tusquets, pp. 26-29.

Valéry, Paul (1948). «Mémoires d'un poème», en Varietés V. Paris: Gallimard.

Fecha de recepción: 19 de julio de 2011

Fecha de aceptación: 19 de diciembre de 2011 